\title{
Government Expenditure on Education, Economic Growth and Long Waves: The Case of Portugal*
}

\author{
Ana Bela Nunes \\ GHES/ISEG, Universidade Técnica de Lisboa, Portugal
}

Recent case studies on European economies have analysed the evolution of aggregate series for government expenditure on education and its relation to cyclical economic growth in the long run. These studies have depicted two different patterns in that relationship. In the case of highly developed economies, namely France, Germany and Great Britain, the evolution of public expenditure on education shows a counter-cyclical behaviour until the Second World War and a pro-cyclical movement thereafter. However, in the case of Spain, a different pattern seems apparent since the expansion phase occurring after the Second World War did not change the counter-cyclical evolution of the Spanish government's efforts to improve the level of education in Spain. In this preliminary approach, the Portuguese case seems to fit the Spanish pattern, once again leaving room for defending the possible existence of an Iberian (or Mediterranean) pattern as opposed to a Northern European pattern.

\section{Introduction}

Most empirical studies on education and economic growth, including both crosssection and time-series studies conducted under distinct theoretical approaches, have repeatedly proved the existence of a significant association (and causality) between the economic performance of national economies and the level of education of their population.

Long-run historical approaches concerning economic backwardness have underlined how a poorly educated, poorly trained and culturally unaware population has been a decisive factor in the occurrence of persistently low productivity levels, low labour mobility, slow structural changes, slow diffusion of innovations (institutional, technological and organisational), preventing sustained economic growth from taking place. Moreover, if an economy, despite its finally succeeding in achieving modern economic growth, is not able to rapidly overcome the human capital accumulation gap, some opportunities will be missed for

\footnotetext{
*Preliminary versions of this paper were presented at the Twentieth Meeting of the Associação Portuguesa de História Económica (Oporto, November 2000) and at the Congress of the Asociación de Historia Económica (Zaragoza, September 2001). I particularly wish to thank Claude Diebolt and Sandrine Michel for their helpful comments on the first draft, as well as Alain Carry and Clara Eugenia Núñez for their critical appraisal of the second version. Some of these comments can only be dealt with through further research into these themes. Obviously all mistakes and shortcomings in the final version remain mine.
} 
achieving the expected catch-up growth, whilst growth rates will remain comparatively small.

Portugal seems to fit perfectly into these frameworks. As I explained in a previous article, ${ }^{1}$ until the 1940s, the human capital embodied in the Portuguese population, taking the literacy rate as a proxy, was too small to allow for a sustained process of industrialisation and development, which only began to take off in the 1950s. On the other hand, although Portuguese growth rates, during the second half of the twentieth century - and especially during its third quarter - were among the highest, Portugal did not achieve similar "economic miracles" to the "Asian tigers" in the 1960s, 1970s or 1980s or Ireland in the 1990s, not to mention Germany and Japan in the 1950s and 1960s. The existence of high levels of human capital, and especially the ability to rapidly overcome the human capital accumulation gap, are among the decisive factors accounting for the exceptional performance of these economies in comparison with the Portuguese economy. ${ }^{2}$

On the other hand, in most societies during the last two centuries, the State has played a decisive role in fostering human capital accumulation, not only during the first stages of growth but even when high levels of development and high levels of GDP per capita have developed efficient market mechanisms.

In the case of Portugal, though State intervention has long been very active in controlling and regulating the economy, its specific role in human capital accumulation has been regarded as weak and inefficient both in the nineteenth century ${ }^{3}$ and in the late twentieth century. ${ }^{4}$ We shall go into this subject in more detail later on.

Meanwhile, recent case studies on European economies, rooted in the systemic regulation theory, have analysed the evolution of aggregate series for government expenditure on education and its relation to cyclical economic growth in the long run. These studies have identified different patterns in that relationship, as explained below. Our aim here is to add a preliminary approach to the Portuguese case and to detect how it fits into these patterns. We are fundamentally concerned here with the empirical results and their basic interpretation. However, this exercise is embedded in some questionable theoretical approaches, while it also invites us to revisit some of the most basic topics in Portuguese economic history, namely the relative backwardness of the Portuguese economy seen from a historical perspective and the role played by

\footnotetext{
${ }^{1}$ Ana Bela Nunes, "Education and economic growth in Portugal: a simple regression approach", Estudos de Economia, XIII/2 (1993), pp. 183-184.

${ }^{2}$ João C. das Neves \& Sérgio Rebelo, O desenvolvimento económico em Portugal (Lisbon, 2001), pp. 23, 98-107. According to recent literature on the role of education in the long-run performance of the Spanish economy, the Spanish case seems to acknowledge most of what has just been said for Portugal. See: Clara-Eugenia Núñez, La fuente de la riqueza. Educación y desarrollo económico en la España Contemporánea (Madrid, 1992); Id., "La educación en el desarrollo económico de la España del siglo XX: Un factor de atraso", in: Antonio Morales Moya (Ed.), Las claves de la España del siglo XX. Las transformaciones económicas (Valencia, 2001), pp. 71-94.

${ }^{3}$ Jaime Reis, "The historical roots of the modern Portuguese economy: the first century of growth, 1850s to 1950s", in: Richard Herr (Ed.), The New Portugal: Democracy and Europe (Berkeley, 1993), pp. 126-148.

${ }^{4}$ Benedict Clements, "The efficiency of education expenditure in Portugal", IMF Working Paper, CLXXIX (1999).
} 
the State in the process of its economic growth. Some questions are asked and some qualifications raised about the suggested interpretations.

In Section Two, some relevant theoretical aspects on economic growth, as well as some questions and remarks underlying these empirical studies, will be briefly put forward against the background of some of the basic specificities of the Portuguese case. They mainly relate to the long-wave perspective on economic growth, the systemic regulation theory and the role of the state in fostering economic growth. Section Three will deal with the empirical analysis, embracing the sources and methodology needed to compute the aggregate series used in the statistical exercise, as well as the interpretation of its main results in the context of Portuguese economic history and education policies. Some concluding remarks and qualifications will be made in Section Four.

\section{The theoretical framework}

Recent case studies on several European economies have looked into the evolution of aggregate series of government expenditure on education and its relation to cyclical economic growth in the long run, following Fontvieille's seminal work on the French case. ${ }^{5}$ From the viewpoint of quantitative economic history, these studies are a theoretical development of the human capital theories that were produced during the economic boom after the Second World War. Actually, they depart from its more deep-rooted, neo-classical formulations and move in the direction of more heterodox approaches, namely the systemic regulation theory. ${ }^{6}$ The context for such a departure is the transformation that took place in the world economy and economic systems after the early 1970s, when there was a reversal of a previous boom phase. This fact fuelled theoretical disagreements between mainstream economics including the endogenous growth theory - and several heterodox schools, while also renewing interest in the various long-wave approaches as a relevant perspective for discussing the performance of the world economy, both from the viewpoint of quantitative economic history and from a theoretical perspective. ${ }^{7}$

\section{The long-wave perspective on economic growth}

The existence of a long-term cyclical pattern in economic development in the course of modern economic growth, reflecting the path followed by the capitalist

\footnotetext{
${ }^{5}$ Louis Fontvieille, "Evolution et croissance de l'Etat français: 1815-1969", Economies et Société, t. X/9-12, série AF/13 (1976); Id., "Education, growth, and long cycles. The case of France in the nineteenth and twentieth centuries", in: Gabriel Tortella (Ed.), Education and economic development since the industrial revolution (Valencia, 1990).

${ }^{6}$ Robert Boyer \& Yves Saillard (dir.), Théorie de la régulation. L'état des savoirs (Paris, 1995).

${ }^{7}$ However, on the subject that is of most concern to us here, such distinct economic paradigms as the endogenous growth theory and the systemic regulation theory - to mention only some of the most recent approaches - have produced fairly convergent conclusions on the importance of cumulative improvements in education to economic development, namely that education has become a driving force for growth. See: Fontvieille, "Education, growth and long cycles", p. 324 \& Robert Lucas Jr., "Making a miracle", Econometrica, LXI/2 (1993), p. 270.
} 
world economy, has turned into one of the most controversial subjects in analyses of economic growth, especially during the acute depressions of the 1930s and 1970 s. Actually, both theoretical and statistical analyses have disputed the empirical evidence and the explanations for such long-wave fluctuations and their periodicity. ${ }^{8}$

However, most long-term analyses of economic growth end up more or less explicitly accepting the Kondratieff cycle - at least its broader post-Schumpeterian version - as a useful chronological framework for examining the successive waves of innovations (technical, organisational, institutional, geographical), underlying the process of economic development and its basic structural transformations.

Although a number of diachronisations are apparent in the evolutionary rhythm of different national economies, ${ }^{9}$ it seems possible to point to the existence of four Kondratieff cycles $(\mathrm{K})$ in the capitalist world economy, broadly speaking in keeping with the following approximate synthetic dates and taking economic activity into consideration as a whole: ${ }^{10} \mathrm{~K} 1$ : 1780s-1840s; K2: 1840s-1890s; K3: 1890s-1940s; K4: 1940 s- . . .

Each long wave, averaging a time span of fifty to fifty-five years, alternates an expansion phase with a depression phase, meaning basically a period when economic activity loses much of its previous dynamism and economic growth rates fall to relatively low levels. The approximate dates most commonly presented for the turning point in each long wave are, respectively, 1813-1815; 1870-1873; 1914-1920; 1971-1973.

It is beyond the scope of this paper to discuss the explanatory theories developed regarding long waves, but, as has been implicitly stated above, the Schumpeterian interpretation has more recently gained momentum: ${ }^{11}$ each upswing in the

\footnotetext{
${ }^{8}$ It is beyond the scope of this paper to go into this matter in further detail. According to some economists and economic historians, the available historical evidence suggests that national economies do not show a synchronised pattern of economic fluctuations. On the other hand, the existence of endogenous, supply-oriented explanations for the occurrence of a cyclical process of a determinate periodicity is also refuted. Ad hoc "system-shocks" some of non-economic origin - are considered to be major causes of policy and institutional transformations that affect economic performances (Angus Maddison, Phases of Capitalist Development [Oxford, 1982], pp. 66-85). For a summarised review of this subject, see also: Solomos Solomou, "Kondratieff cycle", in: Peter Newman, Murray Milgate \& John Eatwell (Eds.), The New Palgrave. A dictionary of economics (London/Basingstoke, 1987), pp. 60-62 and, for a recent survey, Eric Bosserelle, "Le cycle Kondratiev: mythe ou réalité?", Futuribles, CCLXVII (2001), pp. 63-78. For a comprehensive analysis of this subject, see also: Christopher Freeman (Ed.), Long Wave Theory (Cheltenham, 1996).

${ }^{9}$ As the contemporary world economy was set up during the so-called first globalisation process, diachronisation became less evident as a result of closer economic integration between capitalist economies.

${ }^{10}$ The earlier analysis developed by Kondratieff was basically supported by the statistical study of the time series of prices of different types (including wages, interest rates and trade) and, to a much lesser extent, of the time series of quantities for the largest and most highly developed economies in the 1920s: France, United Kingdom, United States and Germany.

${ }^{11}$ Evolutionist and, more broadly speaking, neo-Schumpeterian approaches should be mentioned as relevant theories underlying a long-wave perspective. Innovation, knowledge, technological systems and institutions play a crucial role in the theories developed about economic dynamics. See: Freeman, Long Wave Theory, pp. 125-424.
} 
economy is driven by the diffusion of a cluster of fundamental innovations (lato sensu), which induces a wave of new investments, creates new structures and generates great dynamism. However, a time comes when the positive impact of the wave of innovation begins to fade and a period of depression and "creative destruction" arises, leaving room for a new wave of innovations and investment.

\section{The systemic regulation theory. The role of education in a long-run perspective}

The case studies available on the evolution of aggregate series of government expenditure on education and its relation to cyclical economic growth in the long run relate to four large European economies: France, ${ }^{12}$ Germany $^{13}$ and Great Britain, ${ }^{14}$ which all sustained their economic growth at a more or less early date, in the nineteenth century, ${ }^{15}$ and Spain, ${ }^{16}$ a latecomer to modern economic growth, which, like Portugal, only succeeded in joining the more developed European economies after the Second World War.

These studies have illustrated two different patterns in the relationship under observation. In most cases, namely France, Germany and Great Britain, the evolution of public expenditure on education shows a counter-cyclical behaviour until the Second World War - meaning relatively higher public investment in education during depression phases - and a pro-cyclical movement - meaning relatively higher public investment in education during expansion phases thereafter. However, in the case of Spain, a different pattern is apparent, for the expansion phase after the Second World War did not change the counter-cyclical evolution of the Spanish government's efforts to improve the level of education in Spain.

In the introductory chapter of her doctoral dissertation, ${ }^{17}$ Sandrine Michel makes a clear presentation of the basic ideas that may help to explain the more common pattern just described. These mainly concern the part played by education in the systemic regulation theory in a long-run perspective. ${ }^{18}$ Briefly:

a) The nature of the relationship between education and growth is governed by the changes that have taken place in the (capitalist) socio-economic system. These are changes that induce parallel transformations in the mode of its regulation (meaning the actions taken to encourage the progress of material

\footnotetext{
${ }^{12}$ Fontvieille, "Education, growth and long cycles".

${ }^{13}$ Claude Diebolt, Éducation et croissance économique. Le cas de l'Allemagne aux XIXe et XXe siècles (Paris, 1995).

${ }^{14}$ Vincent Carpentier, Développement éducatif et performances économiques au Royaume-Uni: 19 ème et 20ème siècles (Doctoral dissertation, Montpellier, 2000).

${ }^{15}$ Alexander Gerschenkron, Economic Backwardness in Historical Perspective. A Book of Essays (New York, 1965) treats France and Germany as intermediate cases of economic backwardness in the nineteenth century.

${ }^{16}$ Claude Diebolt, "Government expenditure on education and economic cycles in the nineteenth and twentieth centuries. The case of Spain with special reference to France and Germany", Historical Social Research, XXIV/1 (1999).

${ }^{17}$ Sandrine Michel, Education et croissance économique en longue période (Paris, 1999).

${ }^{18} \mathrm{~A}$ summarised presentation of the theory is produced by Louis Fontvieille in the foreword to Michel, Education et croissance économique en longue durée, pp. 5-13.
} 
productive forces and labour productivity and to overcome the periodical crises and depressions arising from contradictions in the development of the economic system). ${ }^{19}$

b) Before the Second World War, the efforts made to allocate resources to education were cyclical and located in the long depression phases (physical capital devaluation periods). Such efforts would enhance the value of the labour force, raising its productivity and adapting it to the new requirements of the ongoing process of innovation. The new accumulation cycle, coinciding with the new boom phase and with the diffusion of innovations, would again be a period of relatively intense investment in physical capital (detrimental to human capital), whose returns would be quite high as a result of the previous development of the labour force. ${ }^{20}$ As such, education is a response to the demands of the productive sphere and a vital expenditure in enhancing the value of capital.

c) After 1945, the increase in expenditure on education is seen to be greater during periods of prosperity, 1945-1973, and its growth slows down during periods of depression, 1973-. ... This reverse situation to a pro-cyclical relationship between education and economic performance is interpreted as a change in the economic system and its mode of regulation and referred to as a process of autonomisation. Education and the accumulation of knowledge is no longer a corrective factor in overcoming contradictions that are detrimental to the accumulation process. It becomes a decisive part of the "qualitative development of men" - together with such phenomena as healthcare, sports and culture in general - a direct source of growth operating through a logic of its own. An ever greater section of the labour force is used to produce those services directly linked with the "transformation of men themselves" and this leads to a major transformation in the mode of production, where a significant part of education and training in general, administered on a cumulative, lifelong basis, is not directly productive. ${ }^{21}$

d) From a prospective viewpoint, the time will come when the mode of regulation inherent in the "qualitative development of men" will be imposed on the "accumulation mode of regulation".

The Spanish exception is not systematically explained by Diebolt. However, the perverse effects of the Spanish civil war, the relative backwardness of the Spanish economy and "the comparative neglect of the Spanish state with regard to the development of schooling" ${ }^{22}$ represent three sound explanatory hypotheses.

\footnotetext{
${ }^{19}$ For a systematic explanation of both the concept of regulation and the theory of the structural regulation of the capitalist economy and its relation to long cycles, namely Kondratieff's long waves, see: Diebolt, Éducation et croissance économique, Chapter 1.

${ }^{20}$ There are also other formulations using much more evidently neo-Marxist reasoning and concepts, namely by Fontvieille.

21 "Enfin, à ce stade, une part significative, et croissante, du coût de reproduction et de développement de la force de travail est directement prélevée sur le produit sans passer par la forme salaire. La valeur de la force de travail incorpore ainsi des composantes non marchandes" (Louis Fontvieille, "Préface", in: Michel, Education et croissance économique en longue période, p. 12).

${ }^{22}$ Diebolt, "Government expenditure on education", p. 16.
} 
In spite of the similarities between Portugal and Spain as far as political developments in the last two centuries are concerned, ${ }^{23}$ Portugal did not experience the dramatic social and economic impact of a prolonged civil war in the twentieth century. The second and third explanatory hypotheses, however, are facts that have been shown to be relevant by research into the economic history of Portugal. These will be explored below with reference to the Portuguese case.

\section{The role of the state}

Gerschenkron's perspective on the importance of state initiatives for implementing industrialisation (and sustained economic growth) in the case of backward economies, ${ }^{24}$ as well as the more technical approaches in which endogenous growth models describe how cross-country differences in government's economic policies account for differences in economic performance ${ }^{25}$ seems suitable for approaching Portuguese economic growth within a general historical perspective, i.e. as a latecomer to modern economic growth, and, more specifically, for studying the role of the Portuguese state, and of its public finance, in providing human resources of suitable quality over the last two centuries.

Moreover, this broad perspective fits quite well into the idea of the basic economic functions to be performed by the public sector according to the theory of public finance: ${ }^{26}$ the allocation function - public provision of public goods; the distribution function - adjustments in the distribution of income and wealth; the stabilisation function - control of the level of economic activity and price stability and its effects on employment and external balances; and, still a very important non-budgetary function, the provision of a proper institutional background, including a legal structure to which economic life must conform.

In relation to the specific case of education, there are technical reasons for the public sector being involved in the provision of education, if not through direct provision, at least through some kind of subsidy to private sector purchases. In fact, although it is not a typical public good, but a mixed good, education spending generates positive external effects (social gains) and some kind of market failures may arise, as in the case of credit markets, which may lead to underinvestment in human capital by the private sector. ${ }^{27}$ As far as distribution is concerned, education policy may help to reduce inequalities in the distribution of income, which are highly correlated with inequalities in educational investment. More equal distribution of education may reduce differentials in private

\footnotetext{
${ }^{23}$ António Telo \& Hipolito de la Torre Gómez, Portugal e Espanha nos sistemas internacionais contemporâneos (Lisbon, 2000).

${ }^{24}$ Actually, Gerschenkron did not have in mind national experiences similar to the Portuguese case, when he developed his theory on economic backwardness in the nineteenth century. See: Gerschenkron, Economic Backwardness in Historical Perspective.

${ }^{25}$ Sérgio Rebelo, "Long-run policy analysis and long-run growth", Journal of Political Economy, XCIX/3 (1991).

${ }^{26}$ Richard Musgrave \& Peggy Musgrave, Public Finance in Theory and Practice (Tokyo, 1980), pp. 6-23 [First edition: 1973].

${ }^{27}$ For an interesting discussion on the degree of rivalry and excludability of human capital, knowledge and technological change, see: Paul Romer, "Endogenous Technological Change", Journal of Political Economy, XCVIII/5 (1990).
} 
gains. As for stabilisation and growth, public expenditure in education will produce tangible social and economic returns, such as the ability to add new knowledge, to produce and diffuse technological change and innovations in general, to foster economic structural changes, inducing productivity gains, as well as to provide more diffuse, intangible gains concerning extra-economic environmental aspects.

The importance of these state economic functions may be particularly acute in a comparatively backward economy, as in these cases there may arise significant market malfunctions, on the one hand, or cultural and social rigidities, on the other hand. Low GDP per capita, together with very high illiteracy rates, may lead to a low demand for education consumption and high unitary supply costs; slow structural changes may give rise to low expectations on the marginal rates of return of education; financial and credit markets may lack a proper institutional background and sufficient diversification and flexibility to support private investment in education. All this may lead, as it did in the case of Portugal, ${ }^{28}$ to a very slow initial process of accumulation of the stock of human capital, ${ }^{29}$ unless the political will is sufficiently strong to break through basic vicious circles.

\section{The empirical analysis}

\section{The available series}

As a result of the research undertaken during the last two decades into contemporary Portuguese economic history, a significant qualitative and quantitative improvement in the production of long, homogeneous and comparable statistical series on aggregate economic variables is apparent. Most of them have recently been gathered together in a fairly comprehensive collection of Portuguese historical statistics, ${ }^{30}$ much in line with similar information available for many national economies for a long time. The retrospective long series on public finance, namely on public expenditure, on national accounts, namely on GDP, price indexes and GDP deflators - the ones that will most concern us here - are among the aggregate series that have recently been produced and extensively used to enlighten and refute traditional views on the Portuguese economic performance over the last two centuries. Nevertheless, the best series available for Portugal are not yet as sound, as long or as diversified as similar ones existing for many other European economies. Naturally, we are aware of the fact that future improvements in data may eventually jeopardise some of the results and conclusions of this paper.

\footnotetext{
${ }^{28}$ On this matter, see in particular: Reis, "The historical roots of the modern Portuguese economy"; Rui Ramos, "Culturas da alfabetização em Portugal: uma introdução à história da alfabetização no Portugal contemporâneo”, Análise Social, XXIV (1988); Id., “'O chamado problema do analfabetismo': as políticas de escolarização e a persistência do analfabetismo em Portugal (séculos XIX e XX)", Ler história, XXXV (1998); Sérgio Grácio, Ensinos técnicos e política em Portugal, 1910/1990 (Lisbon, 1998).

${ }^{29}$ Alda Domingos, "Sistema de ensino e perfis de qualificações no quadro do crescimento económico português (período de 1940-1993)", Estudos de Economia, XIX/3 (1999), p. 381.

${ }^{30}$ Nuno Valério (Coor.), Portuguese Historical Statistics (Lisbon, 2001).
} 


\section{Public expenditure on education}

The aggregate long series on public expenditure (both total expenditure and expenditure on education) taken for this analysis and reproduced in Appendix One, are included in Chapter Nine, Table 9.5, "Functional composition of public expenditure, 1851-1998", of the above-mentioned collection of Portuguese historical statistics. ${ }^{31}$ Data cover the period from the fiscal year of 1851-1852 to the fiscal year of 1998. Education expenditure includes only public account figures on administrative services concerning education - primary, secondary, higher and special education - science, research and culture. Total public expenditure includes public debt. The series were computed from the Conta Geral de Estado (State Account) or the previous corresponding official publications ${ }^{32}$ until 1977; $^{2}$ thereafter, the values are the ones that are directly available in the official publication. The construction of the series before 1977 followed the criteria used in the Conta Geral de Estado for 1977 and thereafter.

Systematic autonomous yearly statistics on education were only organised from 1940 onwards in Estatísticas da Educação (Educational Statistics). For the period 1946-1965, these statistics gather together data on public expenditure on education taken both from public accounts and from local administrations Câmaras Municipais and Juntas Distritais. As shown in Appendix Two, the relative share of the expenditure of local administrations on education amounted to a steady ten per cent during that period. At the same time, there are only minor differences between the public account figures on education computed by E. Mata and those computed by the official publication, for the period 1940-1968; the correlation coefficient is 0.996 .

\section{Gross domestic product and its deflator}

We are using the new series of Portuguese retrospective national accounts, namely GDP at current prices, published in Chapter Six, Table 6.6, "Gross domestic product and its variations", of the Portuguese Historical Statistics, for the period 1837-1993. ${ }^{33}$ They take into account all the latest official (National Statistical Institute) and semi-official (Portuguese Central Bank research department) revision of similar data for the period 1953-1993 to compute data back to 1837 . Briefly, the estimate of nominal GDP was computed using proxy variables, namely exports, imports, government expenditure and fiscal revenue, as was the case in a previous paper. ${ }^{34}$ For the deflator, we used the series estimated by N. Valério, ${ }^{35}$

\footnotetext{
${ }^{31}$ Eugénia Mata, "Public finance and public debt", in: Valério, Portuguese Historical Statistics, pp. 702-707.

${ }^{32}$ Accounts of the respective ministries and Conta de Receita e da Despesa do Tesouro Público up to the fiscal year of 1882-1883 and Conta Geral da Administração Financeira do Estado from $1883-1884$ to $1919-1920$.

${ }^{33}$ Nuno Valério, "National accounts", in: Valério, Portuguese Historical Statistics, pp. 536-543. These retrospective values and the methodology used to estimate them were presented and discussed in: Nuno Valério, "Recent developments on Portuguese retrospective national accounts", GHES Working Paper, XII (1998).

${ }^{34}$ Ana Bela Nunes, Eugénia Mata \& Nuno Valério, "Portuguese economic growth 1833-1985", Journal of European Economic History, XVIII/2 (1989), pp. 291-330.

${ }^{35}$ Valério, "Recent developments", pp. 23-27.
} 
which uses a cost of living index as a proxy variable. ${ }^{36}$ Needless to say, there are numerous theoretical and technical problems arising from the use of this type of deflator to compute the behaviour of the volume of expenditure, especially for such a long period. Unfortunately, any discussion as to the choice of the most appropriate index for assessing the volume of education ${ }^{37}$ is useless for practical purposes in the case of Portugal, since there are no feasible alternatives to fit such a long period.

\section{Empirical results}

The growth of expenditure on education

For the period 1851-1993 (142 years) - amounting to almost a century and a half, beginning in the mid-nineteenth century - the series of statistics relating to state expenditure on education in Portugal (see Figure 1 below) show an average annual growth rate in volume, taken from the exponential adjustment, ${ }^{38}$ of 5.2 per cent, a significant rise, in keeping with the evolution of similar series for other economies such as France, Germany or the United Kingdom, which also show high rates for very long periods: 4.42 per cent (172 years) for France, ${ }^{39} 6.25$ per cent (161 years) in the case of Germany, ${ }^{40} 6$ per cent (156 years) in the case of the United Kingdom. ${ }^{41}$

Again, in similarity with these cases, state expenditure on education in Portugal shows phases of slow growth (and even negative growth) alternating with phases of rapid growth. However, a Kondratieff pattern in the evolution of this variable, which seems to be apparent in the cases already referred to, is hardly (much less) conspicuous in the case of Portugal, especially during the "long" nineteenth century.

Two different types of factors may account for this. One reflects the slow pace of capitalist development in Portugal, the other concerns the economic blueprint implemented by the Portuguese governments in the second half of the nineteenth century.

On the one hand, Portugal failed both to sustain its economic growth and to deepen its integration into the world economy before the outbreak of the First World War. As far as average standards of living are concerned, after three

\footnotetext{
${ }^{36}$ There is no explicit deflator of GDP published in Valério, "National accounts", but the deflator implicit in real GDP figures (Table 6.6) is actually the one published in Valério, "Recent developments". For methodological details see: Nunes, Mata \& Valério, "Portuguese economic growth", pp. 319-323.

${ }^{37}$ For more information on this subject, see: Diebolt, "Government expenditure on education", pp. 10-12.

${ }^{38} \ln (\mathrm{SEE})=-97.378+0.052 \mathrm{t} ;$ se $\left(B_{1}\right)=0.001$. (SEE $=$ state expenditure on education $) ;$ df $=141 ; \mathrm{r}=0.966 ; \mathrm{r}^{\prime 2}=0.933 ; \mathrm{t}=44.365(0.0001) ; \mathrm{F}=1966.469(0.0001)$.

${ }^{39}$ Fontvieille, "Education, growth and long cycles", p. 321.

${ }^{40}$ Claude Diebolt, "La croissance des dépenses publiques d'éducation en Allemagne: 1829-1989", International Review of Education, XLII/2 (1996), p. 468.

${ }^{41}$ Vincent Carpentier \& Claude Diebolt, "Education and economic development. Germany and the United Kingdom in the 19th and 20th centuries" (Unpublished paper, Montpellier, 2000), p. 10.
} 


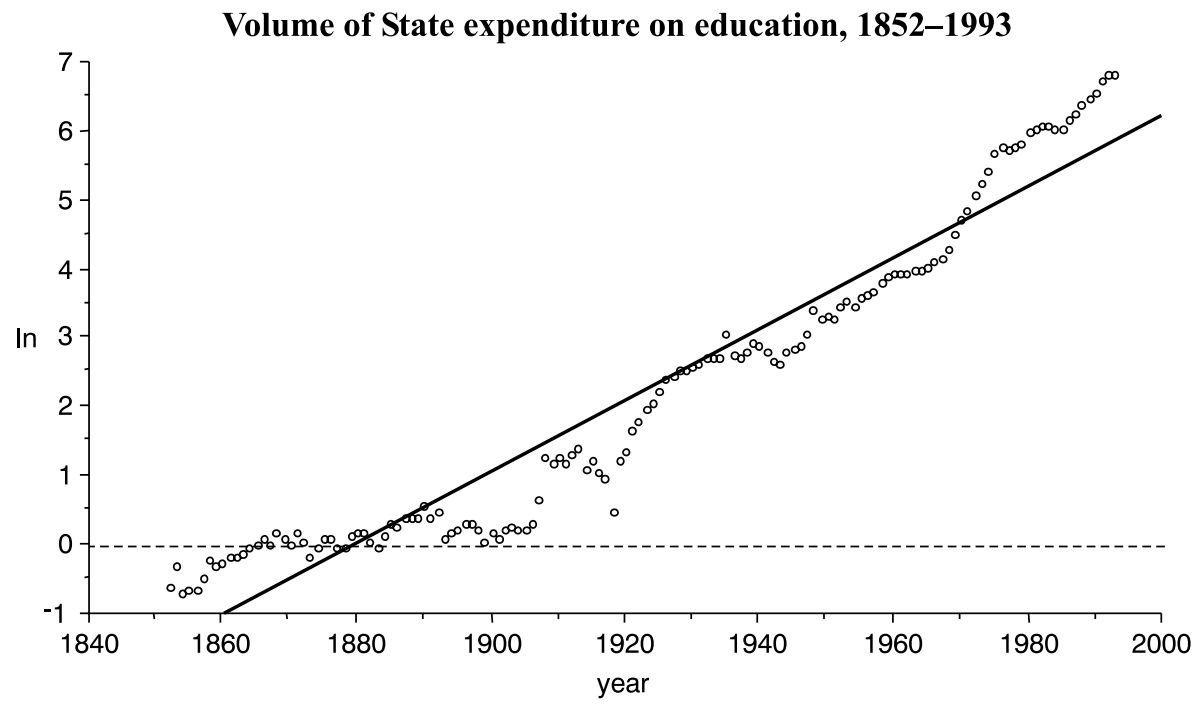

Figure 1 .

decades (1860s-1880s) of some growth (average rate of growth of GDP per capita: 2.1 per cent), and despite some very sharp, short-run crises, typical of a traditional, agrarian economy, there then followed a period of almost complete stagnation from the 1890s to the 1910s (average rate of growth of GDP per capita: 0.3 per cent) (see Figure 2 below). Altogether, there was a relatively small average rate of growth of GDP per capita, ${ }^{42}$ which can be allied to the fact that there was no significant structural change, namely in the sectorial pattern of employment and output - in 1890, the agricultural labour force was still 61 per cent of the total labour force and by 1911 this share had still only fallen to 57 per cent. ${ }^{43}$ As for the degree of integration of the Portuguese economy into the world economy, several recent works have shown how comparatively small this was until the interwar period, especially for such a small economy as Portugal. ${ }^{44}$ This fact, which concerned trade (imports averaged 5 per cent of GDP), capital flows and migration (averaging less then 1 per cent of the total population), probably proved to be very detrimental to productivity growth, by reducing international diffusion mechanisms, particularly in the case of technical progress, and by reducing the potential incentives towards more intensive capital processes resulting from significant wage increases.

\footnotetext{
${ }^{42}$ Valério, "Recent developments", p. 14.

${ }^{43}$ Ana Bela Nunes, "Economic activity of the population", in: Valério, Portuguese Historical Statistics, Table 4.1, pp. 164-166.

${ }^{44}$ Jaime Reis, "O atraso económico português em perspectiva histórica (1860-1913)", Análise Social, XX (1984); Kevin O'Rourke \& Jeffrey Williamson, "Around the European periphery 1870-1913: globalization, schooling and growth”, European Review of Economic History, I/2 (1997); M. Paula Fontoura \& Nuno Valério, "Foreign economic relations and economic growth in Portugal, 1840s-1980s: a long-term view", Economies et Sociétés, XXVI, Series AF (2000), pp. 175-206.
} 


\section{Gross Domestic Product per capita (1914=100)}

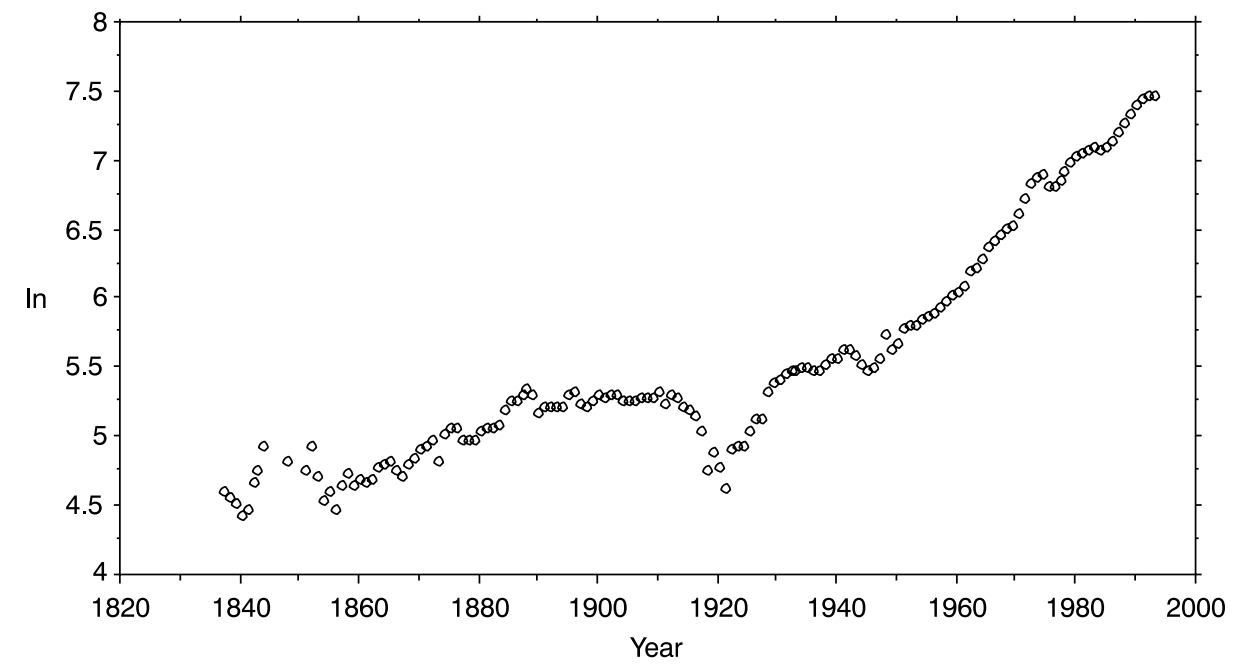

Figure 2.

On the other hand, most of the second half of the nineteenth century was the period of implementation of the so-called "liberal blueprint" ${ }^{45}$ Most public investment then centred on promoting material infrastructures, particularly transport and communication, resulting in increasing public indebtedness and, finally, in serious financial problems (partial bankruptcy in the early 1890s). The negative effects of this crisis were to last several decades, forcing the state to reduce its investments and operate under much harder borrowing conditions. ${ }^{46}$

From the First World War onwards, however, a counter-cyclical path, close to the pattern of the Kondratieff cycles, becomes more apparent. In fact, during the interwar period (1918-1938) - the depressive phase of the third Kondratieff cycle the volume of state expenditure on education grew at an average rate that was far above the general trend - 12.1 per cent as against 5.2 per cent. ${ }^{47}$ This was the period when the First Republic and the Estado Novo (New State) governments allocated a comparatively significant part of their income to promoting education (averaging 9 per cent of total public expenditure, as compared to a mere 3 per cent in preceding decades), especially primary education. In this period, the literacy rate increased from 25 per cent (1910) to 41 per cent (1940), passing beyond the 40 per cent threshold needed to achieve modern economic growth. A similar pattern occurred after the late $1960 \mathrm{~s}$, at the onset of the depression phase of the fourth Kondratieff cycle: the average growth rate of $10.6 \%$ for the period 1968-1993 - corresponded to

\footnotetext{
${ }^{45}$ Eugénia Mata, "As três fases do fontismo: projectos e realizações", in: Romero Magalhães et al., Estudos e ensaios - em homenagem a Vitorino Magalhães Godinho (Lisbon, 1988), pp. 413-430.

${ }^{46}$ Eugénia Mata \& Nuno Valério, História Económica de Portugal (Lisbon, 1993), pp. $162-165$.

${ }^{47}$ A turning point may, in fact, be detected from the second half of the 1900s onwards, relating to the so-called "Republican blueprint", which was to be clearly implemented after the First World War (Ibid., pp. 165-169).
} 
an increase in public investment in education to a level of more than 13 per cent of total public expenditure. In this phase, various educational reforms increased the number of years of compulsory education (nine years in 1986), and, especially after 1974, the number of students completing the different levels increased significantly. In contrast, during the expansion phase occurring after the Second World War, when Portugal finally succeeded in sustaining its economic growth and embarked on a rapid catching-up process in relation to the most developed economies, state investment in education, according to expenditure on this item, was relatively low - a 6 per cent annual growth rate, slightly above the long-run average growth rate. In fact, this corresponded to a stagnation in terms of public expenditure, especially in the 1960 s, when expenditure on education amounted, on average, to a mere 8 per cent of total public expenditure. During this period, although some major educational reforms were implemented in the late $1940 \mathrm{~s}^{48}$ and, in particular, in the 1950 s, leading to important achievements in this field - such as an apparent increase in the average years of schooling in the late $1950 \mathrm{~s}^{49}$ and the implementation of a fouryear compulsory education system after 1956 - these did not correspond to a similar effect in terms of public expenditure on education. The main reasons for this were a reduction in the unitary supply cost of primary education as part of the pragmatic effort made to eradicate illiteracy ${ }^{50}$ and an increase in the private supply of education, namely at the secondary level. ${ }^{51}$

In short, the counter-cyclical pattern seems to exist after the First World War and to persist after the Second World War in the case of Portugal, in similarity to the Spanish experience, even if we take only the period after the 1910s and observe the behaviour of the series against the trend. ${ }^{52}$ In the interwar period and after the 1970 s, two depressive phases, the volume of state expenditure on education is above the trend, whilst an opposite pattern can be observed in the 1950s and 1960s, the greatest expansion phase ever (see Figure 3 below).

\section{The evolution of state expenditure on education in relation to total public expenditure}

As far as the evolution of the ratio of state expenditure on education to total public expenditure (including the public debt service) is concerned, most of the basic

\footnotetext{
${ }^{48}$ A fairly broad technical-professional education reform was devised by Pires de Lima as Minister of Education in 1947-1948. It was supposed to be of great importance in the context of the first steps in the industrialisation process. However, its impact proved to be smaller than expected in the short run, as the period of compulsory education was, at that time, a mere three years and the Portuguese capitalist group continued to be fairly insensitive to the importance of providing their workers with professional education and training. Sérgio Grácio, Política educativa como tecnologia social. As reformas do ensino técnico de 1948 e 1983 (Lisbon, 1986).

${ }^{49}$ Domingos, "Sistema de ensino e perfis de qualificações", p. 381.

${ }^{50}$ The main actions taken were the introduction of the Popular Education Plan (Plano de Educação Popular) and the National Campaign for Adult Education (Campanha Nacional de Educação de Adultos.

${ }^{51}$ António Barreto, "Centralização e descentralização no sistema educativo”, Análise Social, CXXX (1995).

${ }^{52} \ln (\mathrm{SEE})=-132,397+0.07 \mathrm{t}$. se $\left(\beta_{1}\right)=0.002 ;(\mathrm{SEE}=$ state expenditure on education $) ;$ $\mathrm{df}=79 ; \mathrm{r}=0.979 ; \mathrm{r}^{\prime 2}=0.958 ; \mathrm{t}=42.579(0.0001) ; \mathrm{F}=1812,978(0.0001)$.
} 
Volume of State expenditure on education, 1913-1993

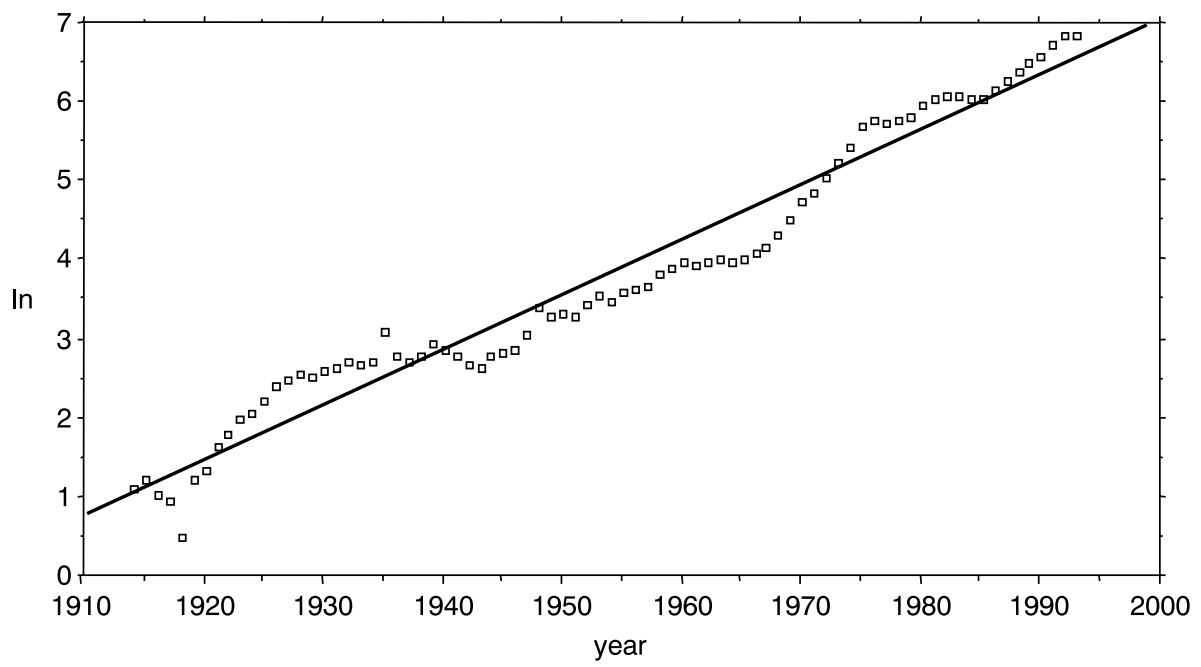

Figure 3.

fluctuations just described are either confirmed or underlined (see Figures 4 and 5 below). The low level and near stagnation of the volume of public expenditure on education during the second half of the nineteenth century (Figure 1) was compounded by a very clear reduction in the relative importance given to education (amidst all their other commitments) by the various governments of that time. This situation lasted until, at the earliest, the last years of the first decade of the twentieth century, or, more pessimistically, the period after the First World War, as explained above. ${ }^{53}$ This fact certainly helps to account for Portugal's inability to sustain its economic growth before the First World War and blames the nineteenthcentury Portuguese governments for making such little investment in human capital, probably taking place at a level far below the possibilities of their actual, although somewhat limited, financial resources. ${ }^{54}$ From 1918 to the late 1940 s, the ratio of state expenditure on education to total public expenditure increased significantly (from 4-5 per cent to 9 per cent) - even taking into account the recovery from the decreasing fluctuations during the two war periods - especially in the 1920s and in the second half of the 1940s. The implementation of the Republican blueprint, felt particularly in the 1920s, meant a significant increase in

\footnotetext{
${ }^{53}$ The fall in the relative share of education expenditure in relation to total public expenditure during the last years of the First World War, which almost returned to what were its lowest ratios since the turn of the nineteenth to the twentieth century, may be reasonably considered inevitable in the context of the war economy. Portugal entered the war in March 1916, which brought a change in the structure of public expenditure that was detrimental to such items as education and health, instead favouring defence, as well as certain specific economic activities, including the efforts made to overcome the problems of shortages.

${ }^{54}$ Jaime Reis, "O analfabetismo em Portugal no século XIX: uma interpretação", in: Alfredo de Sousa et al. (Org.), Nova economia em Portugal - estudos de homenagem a António Manuel Pinto Barbosa (Lisbon, 1989), pp. 95-125.
} 
State expenditure on education to total public expenditure, 1852-1995

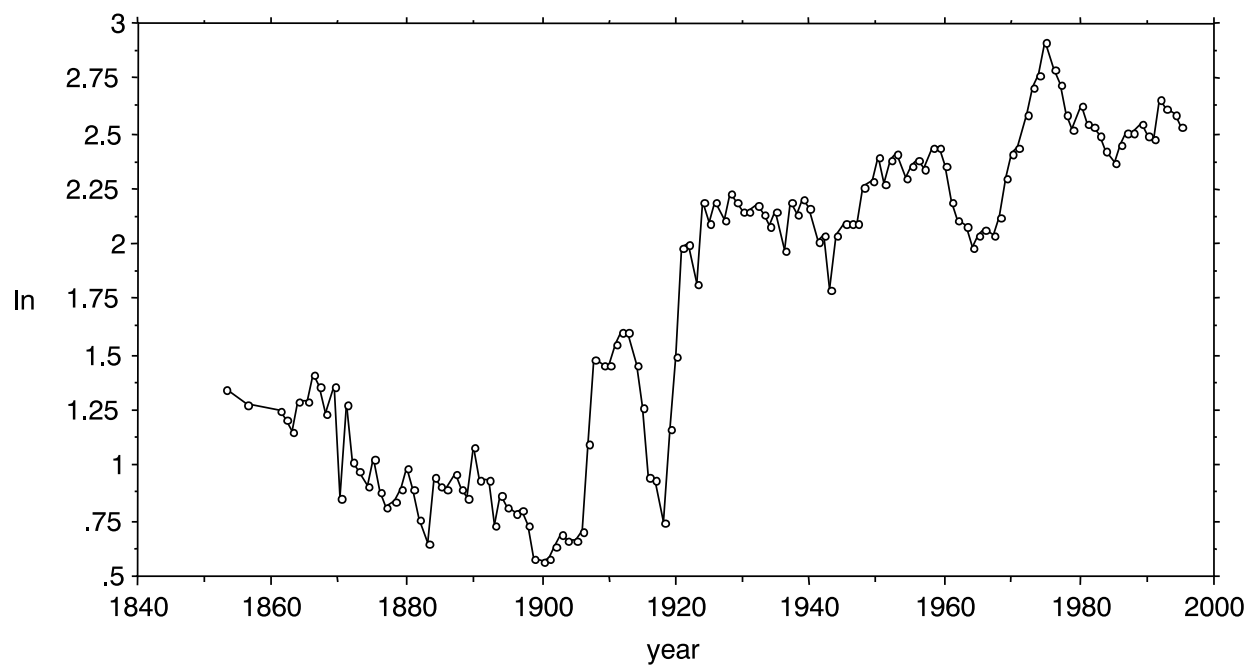

Figure 4.

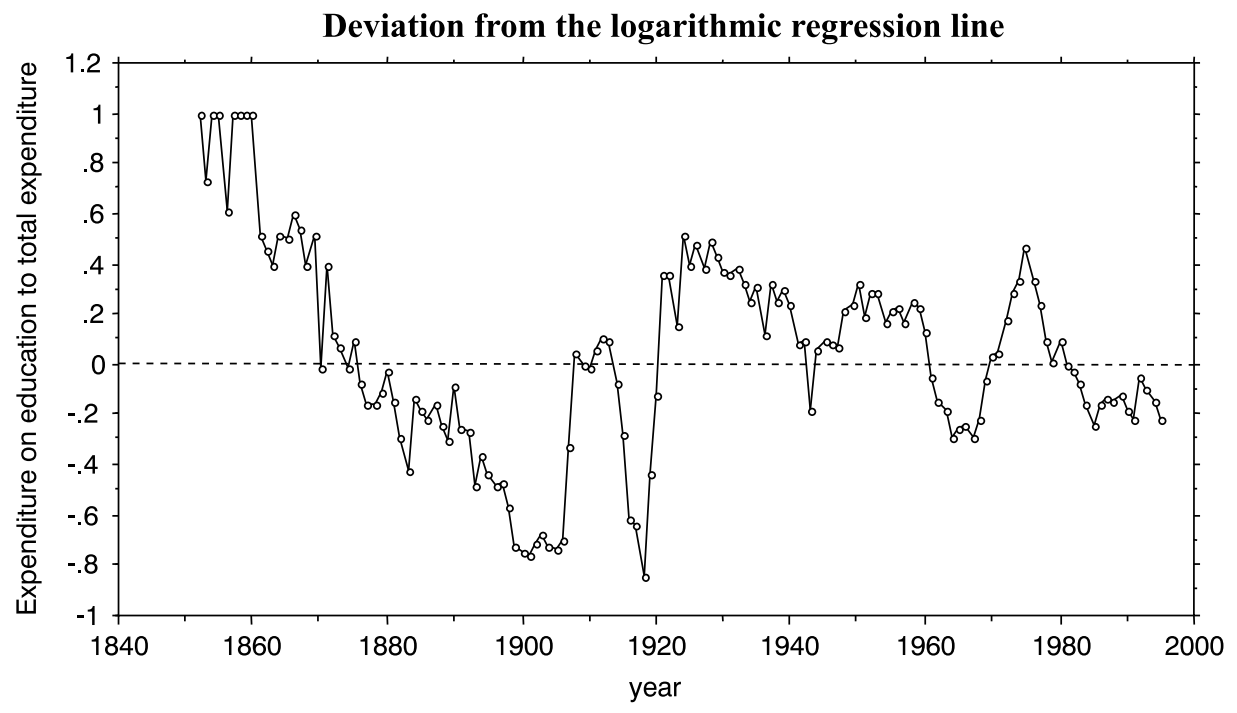

Figure 5 .

the investment made in education (especially primary education). This was maintained for practical purposes throughout the early years of the Estado Novo and was probably one of the most important factors in establishing the pre-conditions necessary to sustain growth over the next few decades. ${ }^{55}$ However, during the

\footnotetext{
${ }^{55}$ Ana Bela Nunes, "Education and economic growth in Portugal: a simple regression approach”, Estudos de Economia, XIII/2 (1993), pp. 181-205.
} 
$1950 \mathrm{~s}$, the ratio almost stagnated and it actually fell below the general trend $\mathrm{d}^{56}$ during the 1960s (corresponding to a decrease in the expenditure on education in relation to total expenditure to some $7-8$ per cent). This was the decade when Portugal consolidated its industrialisation and modernisation process, attaining the highest annual growth rates ever, at a time when the world economy was also in an expansionary phase. Since the 1970 s, the state seems to have increased its relative effort to improve education (dedicating some 14 per cent of its expenditure to education), especially during the 1970s (even before 1974). Such investment resulted in the massification and democratisation of the education system, with questionable qualitative long-term effects. During the 1980s and early 1990s, however, the ratio remained below the exponential long-term regression line. ${ }^{57}$

\section{The evolution of state expenditure on education in relation to gross domestic product}

In the case of the evolution of the ratio of state expenditure on education in relation to GDP - probably the most appropriate variable for discussing the bulk of the relevant question - the main observations made earlier still remain valid (see Figures 6 and 7 below). Moreover, if the deviation from the logarithmic adjustment ${ }^{58}$ is systematically brought into the analysis, such conclusions become very conspicuous.

During the expansion phase of the Kondratieff cycle (1852-1873), the ratio stands above the general trend, although it clearly decreases after 1867. From 1875 to 1919, which, disregarding the First World War period, includes a depression phase and an expansion phase, or just a global phase from Madison's point of view (his second phase of development in the world economy), the ratio remains below the trend although it increases significantly from 1907 onwards, again disregarding the war period.

During the interwar period, a B phase, the ratio remains above the trend, while in the 1946-1972 period, an A phase, systematically negative deviations from the regression line are observed. From the 1970s to the 1990s, the B phase of the 4th Kondratieff, state expenditure on education in relation to GDP is above the trend. Again, the counter-cyclical behaviour of state expenditure on education is the general rule throughout the twentieth century.

\footnotetext{
${ }^{56} \ln (\mathrm{EE} / \mathrm{TE})=-27.343+0.15 \mathrm{t}$; se $\left(B_{1}\right)=0.001 ;(\mathrm{EE} / \mathrm{TE}=$ expenditure on education in relation to total expenditure). $\mathrm{df}=136 ; \mathrm{r}=0.868 ; \mathrm{r}^{2}=0,751 ; \mathrm{t}=20.278(0.0001) ; \mathrm{F}$ $=411.179(0.0001)$.

${ }^{57} \mathrm{~A}$ recent study on education expenditure in Portugal for the 1990s suggests that "(. . ) the gap in educational attainment in Portugal may not be due to inadequate levels of spending, but to how efficiently that spending is translated into educational output". (Clements, "The efficiency of education expenditure in Portugal", p. 22.) In actual fact, both the dropout rates and repetition rates are extremely high in the OECD context. [Fig. 5]

${ }^{58} \ln (\mathrm{SEE} / \mathrm{GDP})=-57.18+0.027 \mathrm{t} ;$ se $\left(B_{1}\right)=0.01 ;(\mathrm{SEE} / \mathrm{GDP}=$ State expenditure on education in relation to gross domestic product) $\mathrm{df}=141 ; \mathrm{r}=0.931 ; \mathrm{r}^{\prime 2}=0.866 ; \mathrm{t}=30.139$ $(0.0001) ; \mathrm{F}=908.357$ (0.0001).
} 


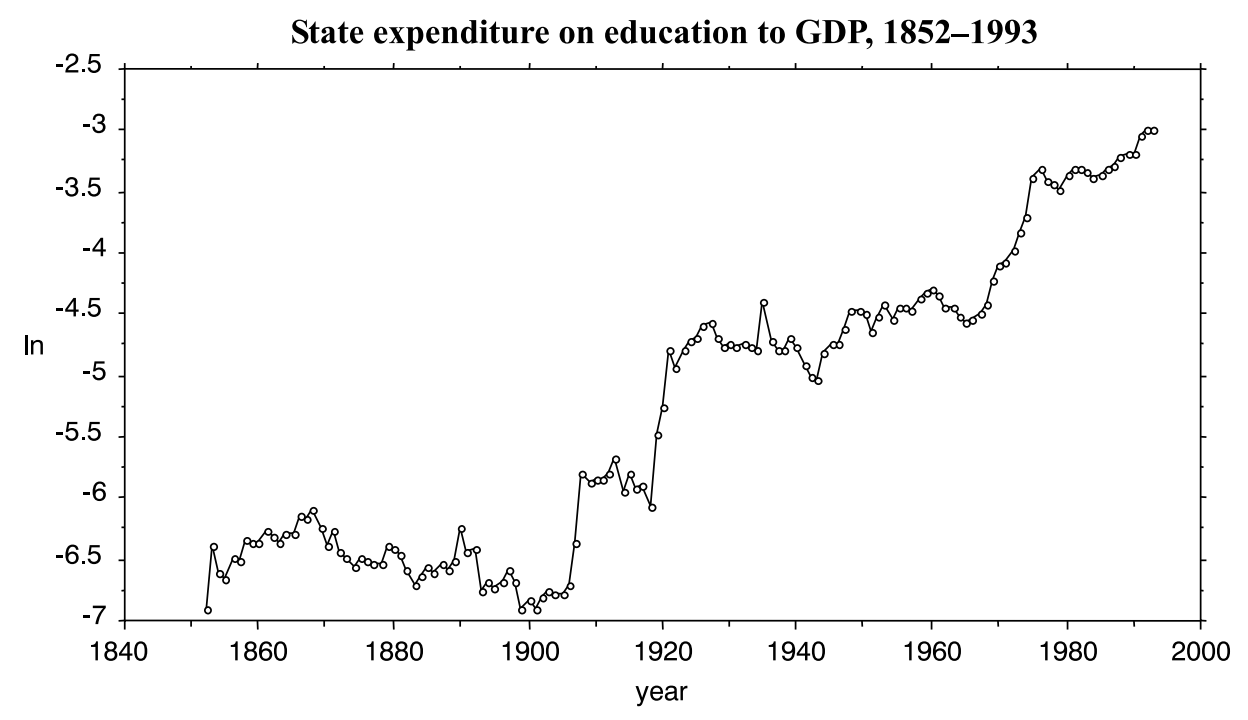

Figure 6.

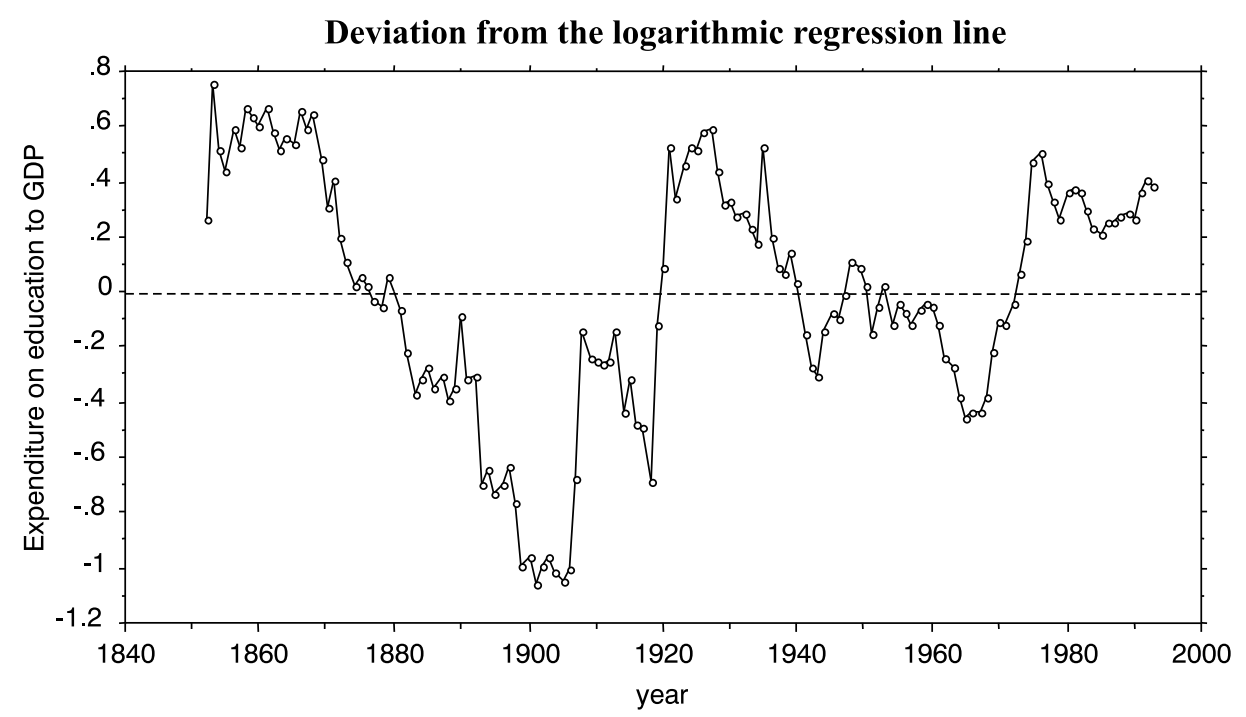

Figure 7.

\section{Concluding remarks}

The first conclusion to be underlined concerns the relevant time span of the analysis in the case of Portugal. As Portugal only entered modern economic growth and become significantly more integrated into the world economy - at least as far as trade is concerned - after the Second World War, the long-wave approach to a very long-run study, namely from the mid-nineteenth century onwards, seems inappropriate within the context of this subject, especially for international comparisons. At best, it may be reasonable to observe the Portuguese experience 
beginning only in the interwar period, when some important pre-conditions for sustaining growth had actually been established. Greater integration in the world economy, ${ }^{59}$ the reaching of the literacy threshold (40 per cent of the total population) ${ }^{60}$ greater public investment in infrastructures and social overhead capital, ${ }^{61}$ should be mentioned among those pre-conditions. In fact, despite the controversial aspects of the new structural economic policy implemented by the authoritarian regime to stimulate economic development after the late $1920 \mathrm{~s},{ }^{62}$ the Portuguese economy behaved comparatively well in the interwar period, ending up in slight convergence towards some of the more highly developed European economies. ${ }^{63}$ Efficient short-term economic policies introduced to tackle the severe depression of the 1930s, namely an original mixture of deflationary and inflationary measures (balanced budget, currency depreciation and low interest rates), some of which were taken in advance, may explain the mild effects of the international crisis and the relatively good performance just mentioned.

In the context of this relative backwardness, and particularly when educational levels are very low, as in the case of Portugal (and Spain) and still many years after the Second World War, it is rational to expect that the so-called autonomisation process of educational attainment, as mentioned above, may be delayed as the axioms of the theory become mitigated or softened. Low GDP per capita and low levels of education - as in the early phases of modern economic growth - will probably imply the absence of stimuli to any significant increase in educational consumption. Meanwhile, the relatively slow change in the nature of the economic system and its mode of regulation, to which the authoritarian regime, ruling from the 1930s to the mid-1970s, contributed (once again, in order to avoid sudden social disequilibria and "social struggle"), may also account for the prevalent counter-cyclical behaviour of expenditure on education in the Portuguese (and Spanish) case up to the present moment.

Economic historians have discussed the existence of patterns of economic performance in Europe in the long run and especially in the European periphery. The case for a Mediterranean pattern ${ }^{64}$ or for a South-Western European pattern ${ }^{65}$

\footnotetext{
${ }^{59}$ Fontoura \& Valério, "Foreign economic relations", pp. 179-180.

${ }^{60}$ Nunes, "Education and economic growth in Portugal", pp. 197-198.

${ }^{61}$ José M. Brandão de Brito \& Ana Bela Nunes, "Política económica, industrialização e crescimento", in: Fernando Rosas (Ed.), Portugal e o Estado Novo (1930-1960) (Lisbon, 1992), pp. 306-351.

${ }^{62}$ Some institutional aspects of the corporatist State, the ideological background of the authoritarian regime of the Estado Novo, namely the so-called "industrial conditioning" process, are supposed to have reduced innovation and the flexibility of the economy, through internal (and external) protectionism. See: João C. das Neves, "Portuguese postwar growth: a global approach", in: Nicholas Crafts \& Gianni Toniolo (Ed.), Economic Growth in Europe since 1945 (Cambridge, 1996), pp. 330-332. 64.

${ }^{63}$ Angus Maddison, L'économie mondiale 1820-1992. Analyse et statistiques (Paris, 1995), p.

${ }^{64}$ See for example: Nuno Valério, "Some remarks about growth and stagnation in the Mediterranean World in the 19th and 20th centuries", The Journal of European Economic History, XXI/1 (1992), pp. 121-133.

${ }^{65}$ Gabriel Tortella, "Patterns of economic retardation and recovery in south-western Europe in the nineteenth and twentieth centuries", Economic History Review, XLVII/1 (1994), pp. 1-21.
} 
has been supported by more or less recent research, which has tended to confirm the common explanations of economic backwardness and divergence up to the Second World War, as well as of an economic recovery and a more or less rapid catching-up process during the second half of the twentieth century. Among the other well-known economic, political and institutional explanations, the low level of human capital in the mid-nineteenth century, its slow accumulation until the 1960s and the low level of efficiency of the education systems, even in recent times, are common features shaping both Portuguese and Spanish economic performance in the long run. The fact that, in terms of sources of economic growth, both economies show insignificant contributions from labour productivity during most (Portugal) or all (Spain) of their "golden ages", while the major role is played by total factor productivity and capital productivity, ${ }^{66}$ seems to reinforce the relative backwardness of both economies in terms of human capital and makes the persistence of the counter-cyclical behaviour of public expenditure on education after the Second World War an inevitable phenomenon.

So, the relative economic backwardness and the type of political regime, which ended up creating many of the pre-conditions for growth and ruled for the first two and a half decades of modern economic growth in Portugal and Spain (also during an expansionary phase for the world economy), may account for the existence of an Iberian pattern as far as the evolution of government expenditure on education is concerned and its relationship with cyclical economic growth in the long run.

Perhaps it takes the time of two Kondratieff cycles for a national economy to sufficiently mature the process of modern economic growth and embark on its own integration process into the world capitalist economy, so that it may then respond fully to the ongoing transformations in the economic system, and inherently, in its mode of regulation, end up displaying the typical pattern of a highly developed economy. Once again, further research into the possible existence of an Iberian (or Mediterranean) pattern as opposed to a Northern European pattern seems to be a tempting avenue to follow.

\footnotetext{
${ }^{66}$ See: Neves, "Portuguese postwar growth", pp. 332-334 for the Portuguese case, and Leandro P. Escosura \& Jorge C. Sanz, "Growth and macroeconomic performance in Spain, 1939-93", in: Crafts \& Toniolo, Economic Growth in Europe, pp. 358-359 for the Spanish case.
} 
Appendix 1: Basic data

\begin{tabular}{|c|c|c|c|c|}
\hline Year & $\begin{array}{l}\text { Total public } \\
\text { expenditure } \\
\left(10^{6} \mathrm{PTE}\right)\end{array}$ & $\begin{array}{l}\text { Public expenditure } \\
\text { on education } \\
\left(10^{6} \mathrm{PTE}\right)\end{array}$ & $\begin{array}{c}\text { Gross Domestic } \\
\text { Product } \\
\left(10^{6} \mathrm{PTE}\right)\end{array}$ & $\begin{array}{c}\text { deflator } \\
(1914=100)\end{array}$ \\
\hline 1852 & • & 0.3 & 300 & 55.6 \\
\hline 1853 & 13 & 0.5 & 296 & 67.4 \\
\hline 1854 & $\bullet$ & 0.4 & 295 & 79.7 \\
\hline 1855 & $\bullet$ & 0.4 & 308 & 78.0 \\
\hline 1856 & 14 & 0.5 & 324 & 94.2 \\
\hline 1857 & $\bullet$ & 0.5 & 335 & 80.7 \\
\hline 1858 & $\bullet$ & 0.6 & 341 & 74.6 \\
\hline 1859 & • & 0.6 & 344 & 81.5 \\
\hline 1860 & - & 0.6 & 346 & 79.0 \\
\hline 1861 & 20 & 0.7 & 366 & 83.2 \\
\hline 1862 & 21 & 0.7 & 388 & 84.2 \\
\hline 1863 & 22 & 0.7 & 402 & 80.7 \\
\hline 1864 & 22 & 0.8 & 428 & 83.3 \\
\hline 1865 & 22 & 0.8 & 429 & 80.6 \\
\hline 1866 & 22 & 0.9 & 415 & 83.2 \\
\hline 1867 & 23 & 0.9 & 430 & 88.3 \\
\hline 1868 & 29 & 1.0 & 441 & 83.2 \\
\hline 1869 & 23 & 0.9 & 455 & 82.4 \\
\hline 1870 & 34 & 0.8 & 470 & 78.1 \\
\hline 1871 & 25 & 0.9 & 469 & 76.3 \\
\hline 1872 & 29 & 0.8 & 497 & 76.3 \\
\hline 1873 & 30 & 0.8 & 528 & 96.0 \\
\hline 1874 & 32 & 0.8 & 563 & 81.6 \\
\hline 1875 & 32 & 0.9 & 595 & 82.4 \\
\hline 1876 & 37 & 0.9 & 599 & 83.2 \\
\hline 1877 & 40 & 0.9 & 613 & 92.6 \\
\hline 1878 & 39 & 0.9 & 612 & 91.8 \\
\hline 1879 & 41 & 1 & 596 & 88.4 \\
\hline 1880 & 37 & 1 & 608 & 83.3 \\
\hline 1881 & 41 & 1 & 634 & 85.0 \\
\hline 1882 & 42 & 0.9 & 650 & 85.9 \\
\hline 1883 & 42 & 0.8 & 649 & 82.4 \\
\hline 1884 & 35 & 0.9 & 678 & 77.2 \\
\hline 1885 & 40 & 1 & 700 & 74.5 \\
\hline 1886 & 41 & 1 & 737 & 76.3 \\
\hline 1887 & 42 & 1.1 & 754 & 74.6 \\
\hline 1888 & 45 & 1.1 & 798 & 74.6 \\
\hline 1889 & 51 & 1.2 & 813 & 79.9 \\
\hline 1890 & 54 & 1.6 & 810 & 88.4 \\
\hline 1891 & 51 & 1.3 & 811 & 85.8 \\
\hline 1892 & 55 & 1.4 & 841 & 87.5 \\
\hline 1893 & 48 & 1.0 & 860 & 89.2 \\
\hline 1894 & 46 & 1.1 & 880 & 90.9 \\
\hline 1895 & 49 & 1.1 & 931 & 86.7 \\
\hline 1896 & 55 & 1.2 & 953 & 87.6 \\
\hline 1897 & 58 & 1.3 & 946 & 93.4 \\
\hline 1898 & 58 & 1.2 & 967 & 96.8 \\
\hline 1899 & 56 & 1.0 & 988 & 95.2 \\
\hline 1900 & 62 & 1.1 & 1019 & 92.6 \\
\hline 1901 & 56 & 1.0 & 994 & 91.7 \\
\hline 1902 & 58 & 1.1 & 998 & 89.2 \\
\hline
\end{tabular}


Appendix 1: (Continued)

\begin{tabular}{|c|c|c|c|c|}
\hline Year & $\begin{array}{l}\text { Total public } \\
\text { expenditure } \\
\left(10^{6} \mathrm{PTE}\right)\end{array}$ & $\begin{array}{l}\text { Public expenditure } \\
\text { on education } \\
\left(10^{6} \mathrm{PTE}\right)\end{array}$ & $\begin{array}{c}\text { Gross Domestic } \\
\text { Product } \\
\left(10^{6} \mathrm{PTE}\right)\end{array}$ & $\begin{array}{c}\text { deflator } \\
(1914=100)\end{array}$ \\
\hline 1903 & 60 & 1.2 & 1033 & 91.7 \\
\hline 1904 & 62 & 1.2 & 1053 & 96.8 \\
\hline 1905 & 62 & 1.2 & 1059 & 95.9 \\
\hline 1906 & 64 & 1.3 & 1068 & 96.0 \\
\hline 1907 & 63 & 1.9 & 1096 & 96.0 \\
\hline 1908 & 77 & 3.4 & 1120 & 96.8 \\
\hline 1909 & 75 & 3.2 & 1137 & 97.6 \\
\hline 1910 & 77 & 3.3 & 1150 & 94.3 \\
\hline 1911 & 70 & 3.3 & 1133 & 99.3 \\
\hline 1912 & 72 & 3.6 & 1191 & 98.4 \\
\hline 1913 & 84 & 4.2 & 1209 & 101.0 \\
\hline 1914 & 70 & 3.0 & 1129 & 100.1 \\
\hline 1915 & 104 & 3.7 & 1208 & 109.9 \\
\hline 1916 & 143 & 3.7 & 1383 & 129.9 \\
\hline 1917 & 153 & 3.9 & 1431 & 149.1 \\
\hline 1918 & 189 & 4.0 & 1737 & 242.9 \\
\hline 1919 & 288 & 9.3 & 2227 & 271.3 \\
\hline 1920 & 367 & 16.5 & 3119 & 426.7 \\
\hline 1921 & 444 & 32.5 & 3870 & 618.2 \\
\hline 1922 & 590 & 43.9 & 6131 & 723.0 \\
\hline 1923 & 1244 & 77.1 & 9299 & 1049.5 \\
\hline 1924 & 1224 & 110.1 & 12133 & 1377.2 \\
\hline 1925 & 1518 & 123.7 & 13450 & 1333.0 \\
\hline 1926 & 1605 & 143.8 & 14203 & 1286.5 \\
\hline 1927 & 1953 & 161.4 & 15344 & 1363.9 \\
\hline 1928 & 1812 & 169.5 & 18249 & 1314.8 \\
\hline 1929 & 1920 & 171.9 & 20304 & 1359.0 \\
\hline 1930 & 2044 & 175 & 19877 & 1302.6 \\
\hline 1931 & 1901 & 163.6 & 19191 & 1180.3 \\
\hline 1932 & 1935 & 172.3 & 19508 & 1160.5 \\
\hline 1933 & 2012 & 171.6 & 19892 & 1159.9 \\
\hline 1934 & 2159 & 174.2 & 20668 & 1169.7 \\
\hline 1935 & 2980 & 256.8 & 20890 & 1171.6 \\
\hline 1936 & 2655 & 192.6 & 21322 & 1195.8 \\
\hline 1937 & 2075 & 186.7 & 22288 & 1234.8 \\
\hline 1938 & 2298 & 195.1 & 23149 & 1203.2 \\
\hline 1939 & 2397 & 217.5 & 23414 & 1144.9 \\
\hline 1940 & 2423 & 210.1 & 24454 & 1189.4 \\
\hline 1941 & 2820 & 212.5 & 29039 & 1309.8 \\
\hline 1942 & 2955 & 228.3 & 34111 & 1544.9 \\
\hline 1943 & 3985 & 239.3 & 36282 & 1709.8 \\
\hline 1944 & 3681 & 283.3 & 35228 & 1750.0 \\
\hline 1945 & 3926 & 319.8 & 36351 & 1860.3 \\
\hline 1946 & 4624 & 374.6 & 42294 & 2090.7 \\
\hline 1947 & 5694 & 464.5 & 46930 & 2143.9 \\
\hline 1948 & 5699 & 548 & 47693 & 1828.0 \\
\hline 1949 & 5661 & 561 & 48599 & 2064.5 \\
\hline 1950 & 5116 & 561 & 50664 & 2020.9 \\
\hline 1951 & 5605 & 549 & 57360 & 2044.2 \\
\hline 1952 & 5852 & 638 & 58678 & 2046.7 \\
\hline 1953 & 6407 & 711 & 58993 & 2062.0 \\
\hline
\end{tabular}


Appendix 1: (Continued)

\begin{tabular}{|c|c|c|c|c|}
\hline Year & $\begin{array}{l}\text { Total public } \\
\text { expenditure } \\
\left(10^{6} \mathrm{PTE}\right)\end{array}$ & $\begin{array}{l}\text { Public expenditure } \\
\text { on education } \\
\left(10^{6} \mathrm{PTE}\right)\end{array}$ & $\begin{array}{l}\text { Gross Domestic } \\
\text { Product } \\
\left(10^{6} \mathrm{PTE}\right)\end{array}$ & $\begin{array}{c}\text { deflator } \\
(1914=100)\end{array}$ \\
\hline 1954 & 6683 & 671 & 62564 & 2078.5 \\
\hline 1955 & 7330 & 779 & 65447 & 2109.2 \\
\hline 1956 & 7597 & 828 & 69943 & 2175.5 \\
\hline 1957 & 8230 & 861 & 74250 & 2207.9 \\
\hline 1958 & 8687 & 1000 & 79191 & 2220.1 \\
\hline 1959 & 9747 & 1116 & 84042 & 2265.9 \\
\hline 1960 & 11336 & 1200 & 88994 & 2289.5 \\
\hline 1961 & 13445 & 1198 & 92648 & 2301.2 \\
\hline 1962 & 14831 & 1225 & 103987 & 2336.8 \\
\hline 1963 & 15700 & 1268 & 107438 & 2324.5 \\
\hline 1964 & 17167 & 1262 & 116626 & 2378.7 \\
\hline 1965 & 18055 & 1403 & 135681 & 2528.5 \\
\hline 1966 & 19621 & 1560 & 144812 & 2579.5 \\
\hline 1967 & 23359 & 1801 & 162217 & 2772.9 \\
\hline 1968 & 25193 & 2112 & 175432 & 2852.1 \\
\hline 1969 & 27713 & 2758 & 188229 & 2985.4 \\
\hline 1970 & 31736 & 3549 & 212358 & 3102.4 \\
\hline 1971 & 36648 & 4177 & 245768 & 3247.0 \\
\hline 1972 & 40868 & 5438 & 289955 & 3467.1 \\
\hline 1973 & 48894 & 7368 & 342817 & 3902.3 \\
\hline 1974 & 63415 & 10091 & 405744 & 4481.4 \\
\hline 1975 & 86620 & 16047 & 469776 & 5456.8 \\
\hline 1976 & 124688 & 20429 & 561947 & 6362.6 \\
\hline 1977 & 158741 & 24161 & 722257 & 7684.4 \\
\hline 1978 & 214802 & 28708 & 893364 & 8922.0 \\
\hline 1979 & 280659 & 34910 & 1135905 & 10557.7 \\
\hline 1980 & 374780 & 51822 & 1476316 & 13038.2 \\
\hline 1981 & 506843 & 64631 & 1773726 & 15227.7 \\
\hline 1982 & 624158 & 78916 & 2144820 & 17885.4 \\
\hline 1983 & 801871 & 97016 & 2740339 & 22426.9 \\
\hline 1984 & 1019106 & 115344 & 3365099 & 27616.7 \\
\hline 1985 & 1333918 & 141953 & 4131014 & 33175.5 \\
\hline 1986 & 1596796 & 185787 & 5048501 & 39111.4 \\
\hline 1987 & 1835167 & 224530 & 5948432 & 42723.8 \\
\hline 1988 & 2324990 & 283741 & 7100357 & 48229.6 \\
\hline 1989 & 2728752 & 348416 & 8388429 & 53199.1 \\
\hline 1990 & 3437901 & 419204 & 10072063 & 58987.2 \\
\hline 1991 & 4596342 & 545749 & 11534190 & 65301.4 \\
\hline 1992 & 4606656 & 655110 & 12951001 & 70782.1 \\
\hline 1993 & 4998046 & 687611 & 13545854 & 74171.0 \\
\hline 1994 & 5450937 & 725263 & - & $\bullet$ \\
\hline 1995 & 6377879 & 804668 & $\bullet$ & - \\
\hline
\end{tabular}

Note: Actually, data from 1852 to 1935 corresponds to 1851-1852 to 1934-1935 according to the fiscal year, which began in July 1 and ended in June 30 .

Sources: see Section on the empirical analysis. 
Appendix 2: Local administration as \% of total state expenditure on education

\begin{tabular}{|c|c|c|c|c|}
\hline Year & $\begin{array}{l}\text { Central State } \\
\text { expenditures } \\
\text { on education }\end{array}$ & $\begin{array}{l}\text { Local administration } \\
\text { expenditures } \\
\text { on education }\end{array}$ & $\begin{array}{c}\text { Total } \\
\text { expenditures } \\
\text { on education }\end{array}$ & $\begin{array}{c}\text { Local } \\
\text { administration } \\
(\%)\end{array}$ \\
\hline 1940 & 215.8 & $\bullet$ & - & • \\
\hline 1941 & 207.4 & - & $\bullet$ & - \\
\hline 1942 & 217.5 & - & • & • \\
\hline 1943 & 218.6 & $\bullet$ & $\bullet$ & $\bullet$ \\
\hline 1944 & 264.9 & - & - & - \\
\hline 1945 & 296.6 & • & $\bullet$ & • \\
\hline 1946 & 337.9 & 43 & 380.9 & 11 \\
\hline 1947 & 413.4 & 50.3 & 463.7 & 11 \\
\hline 1948 & 447.7 & 66.8 & 514.5 & 13 \\
\hline 1949 & 472.4 & 60.5 & 532.9 & 11 \\
\hline 1950 & 482.8 & 63.4 & 546.2 & 12 \\
\hline 1951 & 490.4 & 63.6 & 554 & 11 \\
\hline 1952 & 535.1 & 76.3 & 611.4 & 12 \\
\hline 1953 & 604.2 & 78.5 & 682.7 & 11 \\
\hline 1954 & 657.2 & 91.2 & 748.4 & 12 \\
\hline 1955 & 708.8 & 98.1 & 806.9 & 12 \\
\hline 1956 & 797.1 & 112.2 & 909.3 & 12 \\
\hline 1957 & 823.9 & 126.3 & 950.2 & 13 \\
\hline 1958 & 969.6 & 114 & 1083.6 & 11 \\
\hline 1959 & 1128.7 & 132.9 & 1261.6 & 11 \\
\hline 1960 & 1200.8 & 129.6 & 1330.4 & 10 \\
\hline 1961 & 1194.9 & 135.3 & 1330.2 & 10 \\
\hline 1962 & 1235.8 & 141.1 & 1376.9 & 10 \\
\hline 1963 & 1271.6 & 142.6 & 1414.2 & 10 \\
\hline 1964 & 1272.6 & 145.7 & 1418.3 & 10 \\
\hline 1965 & 1394.3 & 163 & 1557.3 & 10 \\
\hline
\end{tabular}

Sources: Estatísticas da Educação (Statistics on Education). 